\title{
Conflict and Consensus in South African Natural Law Thinking
}

\author{
By AJGM Sanders
}

\section{Introduction}

By "natural law" is meant the ethical standards of the law.

It is the purpose of this paper to outline the various ways of natural law thinking current in South African society, and to investigate whether and how they could be integrated, such with a view to social reform.

It is indeed presumptuous to address so vast a topic in so small a space. However, some general themes and principles may at least be suggested.

\section{The European way'}

In terms of European thinking, law has a distinct secular connotation. In fact, the European conception of law is the outcome of a subtle interplay between Greek, Roman and Christian thoughts, in which the concept of "human rationality" became the linking factor and driving force. In respect of the law's ethical standards, this emphasis on rationality gave per force rise to different theories, called natural law theories. However, over the centuries a common set of natural law principles developed. Rejected by the Marxist world for being too individualistic, and replaced there by the principle of socialist legality, ${ }^{2}$ these natural law principles still hold valid in the West and from part also of South Africa's legal heritage. In the public law field, they are collectively known as the "Rule of Law".

The Rule of Law aims at securing the individual's human rights against governmental encroachments. As authoritatively formulated by the International Commission of Jurists, ${ }^{3}$ it stands for:

(1) respect by all branches of government for the individual's fundamental rights;

(2) the equality of all before the law;

(3) legal certainty;

1 RWM Dias Jurisprudence Butterworths, London, 4ed, 1976; Lord Lloyd of Hampstead Introduction to Jurisprudence Stevens and Sons, London, 4ed, 1979, The Idea of Law Penguin Books, 1964; GW Paton $A$ Text-book of Jurisprudence Clarendon Press, Oxford, 4ed, 1972; Geoffrey Sawer "The Western Conception of Law" in International Encyclopedia of Comparative Law, CF Mohr, Tubingen, 1975, vol II, c1, 14-48.

2 René David and John EC Brierley, Major Legal Systems in the World Today Stevens and Sons, London, 2ed, 1978, 143-283; Imre Szabó, "The Socialist Conception of Law" in International Encyclopedia of Comparative Law vol II, cl, 49-83.

3 The Rule of Law and Human Rights - Principles and Definitions ICJ, Geneva, 1966. 
(4) a just administration of the law;

(5) limitation of governmental powers, which implies a democratic form of government and a separation of powers;

(6) an independent and properly qualified judiciary;

(7) an independent and properly qualified legal profession.

The manner in which these standards were ignored by the forces of colonialism, racism and fascism is well-known. What is not always realized, is that these forces were at their height during the very same period "Legal Positivism" reigned supreme in the West. This was no coindidence.

Legal Positivism, which dates back to the beginning of the nineteenth century, started off as a form of empirical legal thinking, and was in reaction against the speculative nature of the seventeenth and eighteenth century natural law theories. The only real law, it said, was positive law, and the science of law should confine itself to the systematization of positive law. Positive law, it said, was the command of a determinate political sovereign (English positivism) or the will of the State (German positivism). As empirically grounded hypotheses these "command theories" were utterly false, but as intellectual constructions they enabled governments and courts alike to put the stamp of law on measures which flouted even the most basic standards of civilization. ${ }^{4}$

It were the atrocities of fascism and war that led in the Western hemisphere to a revival of natural law thinking. In South Africa, which was spared these atrocities, natural law thinking came to the fore from the 1960's onwards, in reaction to the policy of Apartheid and its machinery of oppressing and degrading laws and practices. ${ }^{5}$

An interesting feature of modern-day natural law thinking is its flexibility. Gone is the rigidity of the old natural law theories. Instead, account is taken of time and place, and the approach has become less individualistic.

A remarkable variant of the modern natural law approach is the doctrine of "consociationalism", of which we hear so much today in South Africa - even the new 1983 Constitution is said to be based on it! ${ }^{6}$

4 In respect of South Africa, cf Hugh Corder Judges at Work Juta, Cape Town, 1984; John Dugard "Some realism about the judicial process and positivism - a reply“ (1981) 98 South African Law Journal 372-387.

5 B Beinart "The Rule of Law" 1962 Acta Juridica 99-138; John Dugard Human Rights and the South African Legal Order Princeton University Press, 1978; CF Forsyth and JE Schiller (eds) Human Rights: The Cape Town Conference Juta, Cape Town, 1979; AS Mathews Law, Order and Liberty in South Africa Juta, Cape Town, 1971, The Darker Reaches of Government Juta, Cape Town, 1978; OD Schreiner The Contribution of English Law to South African Law; and the Rule of Law in South Africa Stevens and Sons, London, 1967; JD van der Vyver Die Beskerming van Menseregte in Suid-Afrika Juta, Cape Town, 1975.

6 John A Benyon (ed) Constitutional Change in South Africa University of Natal Press, 1978; LJ Boulle and LG Baxter (eds) Natal and Kwazulu: Constitutional and Political Options Juta, Cape Town, 1981; LJ Boulle South Africa and the Consociational Option Juta, Cape Town, 1984; Peter Randall (ed) South Africa's Political Alternatives Sprocas publication 10, Johannesburg, 1978; Nic Rhoodie (ed) Intergroup Accommodation in Plural Societies Institute or Plural Studies, University of Pretoria, 1978; DJ van Vuuren and DJ Kriek (eds) Politieke Alternatiewe in Suider-Afrika-Grondslae en Perspektiewe Human Sciences Research Council, Pretoria, 1982; F van Zyl Slabbert and David Welsh South Africa's Options Philip Publishers, Claremont, 1979. 
Consociationalism progresses from the idea that there are "deeply divided societies" where human rights can only be assured by a "grand coalition" of the political leaders of the various groups. Without such coalition there will be no democracy but rather violence and disruption. In a "deeply divided society", government should be by group leadership consensus, and provision should be made for mutual group veto, group proportionality, and as much group autonomy as possible.

\section{The African way ${ }^{7}$}

Religion permeates every aspect of traditional African life. It expresses itself through the arts, myths, proverbs, rituals, customs and laws.

To the uninitiated, traditional African religions may appear to represent fetishism, animism, ancestor worship or polytheism, but this is not a true picture. In fact, European missionaries have found, of ten to their surprise, that they did not need to argue for the existence of God, or faith in a life after death, for both these fundamentals of world religion are deeply rooted in Africa. Although, in traditional African society, there is little ordered worship of the one God, there is a distinct belief in a Supreme Being who is both the creator and upholder of the universe, and as such is closely concerned with law and morality.

It is a common feature of traditional African religions that they expect human life to be conducted according to the laws which the Creator handed down to the ancestors. The latter, it should be noted, are not just regarded as a part of man's experience, but have life and power of their own. Their role is to act as the link between God and man, between the eternal and the temporal values of the community.

African religion is essentially "communal religion". Likewise, African law is essentially

As for the Republic of South Af rica Constitution Act 110 of 1983, its aim, as explained by Prime Minister PW Botha is "to move away from the Westminster system with its 'one man, one vote ( within a unitary state" (Hansard 1 February $1983 \mathrm{col} 131$ ). According to Chris Heunis, the Minister of Constitutional Development and Planning, "[t] he new South African constitution represents a development away from the traditional Westminster-type 'winner-takes-all democracy towards a new kind of politics, with the emphasis on consensus and co-operation between the different groups in South African society" (Sunday Times 26 August 1984). According to government thinking these groups are the "Whites", the "Coloureds" and the "Indians". The new Constitution accordingly excludes Black participation. As the Minister of Cooperation and Development, P Koornhof, explained, "the Government remains convinced ... that the optimum form of selfdetermination for the Black peoples is the gaining of independence in their own territory " Hansard 1 February 1983, col 161). The territory to which the Minister refers, basically consists of the old Native Reserves. There is every indication that the overwhelming majority of Blacks reject the government's dispensation of assigning them to independent "homelands", thereby depriving them of South African citizenship.

7 AN Allott "African Law" in JDM Derrett (ed) An Introduction to Legal Systems Sweet and Maxwell, London, 1968; Eugene Cotran "African Law" in International Encyclopedia of Comparative Law vol II, c2, 157-168; David and Brierley Major Legal Systems in the World Today 505-532; TO Elias The Nature of African Customary Law Manchester University Press, 1956; Max Gluckman "Natural Justice in Africa" 1964 Natural Law Forum 25-44, Ideas and Procedures in African Customary Law Oxford University Press, 1969; Kéba M'Baye "The African Conception of Law" in International Encyclopedia of Comparative Law vol II, cl, 138-158; JS Mbiti African Religions and Philosophy Heinemann, London, 1969; Geoffrey Parrinder Religion in Africa Penguin Books, 1969. 
"communal law". Its primary function is to ensure "social solidarity", or in more practical terms, to preserve the group and to maintain or restore peace within it. Although recognition is given to the individual according to his social position, the emphasis is on his duties and the interests to the group. The group principle expresses itself in almost every branch of traditional African law, and extends to rulers and subjects alike. It is, however, in the traditional African techniques of seeking consensus and reconciliation that the African conception of moral law comes most clearly to the fore.

The modern ideology of "African Socialism" is an of fshoot of traditional African morality. ${ }^{8}$ It traces its roots to traditional African society as characterized by religious feeling, a communal spirit, and a belief in democracy on the basis of government by discussion and consensus. It seeks to preserve these values but in a form conducive to the present-day need for national unification and economic and social progress. In terms of it, the new nations of Africa should strive for new forms of national kinship, in the political, economic and social fields, irrespective of race or tribal origin. To this end, African Socialism presents the idea of the unitary one-party-State, as a modern projection of traditional African government geared at a "Gemeinschaft" (society) rather than a "Gesellschaft" (consociation), at "organic solidarity" rather than "mechanical solidarity". The concept of the one-party-State - embodying equal and free discussion, popular consensus, and popularly controlled leadership - is considered to represent democracy in its true form, and to provide the means for ensuring social solidarity.

In South Africa, elements of African socialist ideology are discernible in Black political writings, and notably in Nelson Mandela's statement in court on 20 April 1964, at the close of the Rivonia Trial. ${ }^{9}$

\section{The Islamic way ${ }^{10}$}

Submission to the will of God is the fundamental tenet of Islam. The law is an expression of the divine will. Called the Shariea, or the divinely ordained "path", it forms an

8 Cf AJGM Sanders "On African Socialism and Natural Law Thinking" (1978) 11 Comparative and International Law Journal of Southern Africa 68-75, "On African Socialism and the Rule of Law" (1982) 15 Comparative and International Law Journal of Southern Africa 299-305; and the authorities referred to there.

9 Nelson Mandela No Easy Walk to Freedom Heinemann, London, 1965, c15, The Struggle is my Life International Defence and Aid Fund for Southern Africa, London, c12, 155-175.

10 Hassan Af char "The Muslim Conception of Law" in International Encyclopedia of Comparative Law vol II, cl, 84-106; JND Anderson "Morality and Law in Islam: the Past and Present" (1977) 11 Studies in Islam 21-40; Chafik Chehata "Islamic Law" in International Encyclopedia of Comparative Law vol II, c2, 138-142; Noel J Coulson A History of Islamic Law Islamic Surveys Series 2, Edinburgh University Press, 1965, "Islamic Law" in Derrett (ed) An Introduction to Legal Systems; David and Brierley Major Legal Systems in the World Today 421-446; Ahmad Hasan "Social Justice in Islam" (1971) 10 Islamic Studies 209-219; MSH Masc umi "Islamic Concept of Human Rights" (1972) 11 Islamic Studies 211-221; John Renard "Muslim Ethics: Sources, Interpretations and Challenges" (1979) 69 The Muslim World 163-177; RM Savory (ed) Islamic Civilization Cambridge University Press, 1976; Joseph Schacht The Origins of Muhammadan Jurisprudence Clarendon Press, Oxford 1950, An Introduction to Islamic Law Clarendon Press, Oxford, 1964. 
integral part of religion and is accordingly considered to be complete and immutable. It guides one towards the fulfilment of one's duties towards God and one's fellow-men. The real sanction for not obeying the law is to fall in a state of sin leading to punishment in the next world.

The Qur'än, being the word of God Himself as revealed to His Messenger, the Prophet Muhammad, constitutes the primary source of the law. Outside the Qur'än, the only other fundamental source is the divinely inspired practice of the Prophet Muhammad. What he said, did, approved or disapproved of on particular occasions - i.e. the Prophet's practice or Sunna - explains and supplements the Qur'än, and ranks alongside it as an equally authoritative source of God's will. It is in the sacred book of the Qur'an and the Prophet's Sunna therefore that one has to look for the ideological superstructure of Islamic law.

Although the Qur'an and the Sunna tend to give specific rules rather than general principles, a definite ideological superstructure is apparent in them. Of crucial importance here is what the Prophet Muhammad saw as his divine task, namely to replace traditional tribal divisions by a Community of the Faithful. Muhammad preached against the stratification of societies into tribes and classes. These had to make way for a consciousness of common humanity, sprung from Adam's clay. Islam teaches that the Community of the Faithful whose only true head is the one God, kind and merciful and the Creator of everything for the well-being of men, is without distinction of birth, wealth, race or nationality, and that the law applies equally to everybody. Not groups of people but man is regarded as the chief work of creation. In fact, God ordered the Angels to bow for man. To injure man's God-given dignity and equality is truly sinful. On the other hand, the individual has a duty to uphold the community, and within the traditional Islamic system of theocratic government had to practise civil obedience.

This, in brief, constitutes the social message of the divine path of Islam, powerful in its tenets and of considerable consequence in the field of social justice.

\section{The Hindu way ${ }^{11}$}

Hindu law, too, presupposes religion. It has its roots in the Dharmaśastra, or the "science of righteousness". Dharma, the divine precepts of which were for the first time put in writing some four thousand years ago, is an expression of God, as the one, unborn, eternal and universal spirit, immanent and transcendent in the universe as its Supreme Being. Dharma is both above and within the law. It signifies the abstract norm which sustains the universe. In a narrower sense it defines man's religious and social

11 David and Brierley Major Legal Systems in the World Today 447-476; Derrett "Hindu Law" in Derrett (ed) An Introduction to Legal Systems; Derrett and TKK Iyer "The Hindu Conception of Law" in International Encyclopedia of Comparative Law vol II, cl, 107-119, "Hindu Law" Ibid c2, 143-156; Robert Lingat The Classical Law of India University of California Press, 1973. 
duties which bear upon him according to his age and status, and to which he must conform in order to liberate himself from the cycle of rebirths and to attain salvation. By salvation is meant a total transcendence of the empirical self and the relative unreality and non-importance of the empirical world. This is not to say, however, that Hinduism is basically an escapism from the world of action and responsibility and that it could not sustain a "social gospel". In fact, in the Bhagavad-Gitä, we find a sublime Hindu theology of action. The Gitā which integrates the "path of devotion" with the "path of action", invites man to engage in activity and take responsibility in a selfless way, with evenness of mind, and in total attachment to God.

The most authoritative contemporary exponent of the "social gospel" within Hindu religion is Mahatma Gandhi (1869-1947). ${ }^{12}$

Gandhi was an ardent advocate of Dharma as the moral law. The moral law he identified with the law of truth, the Absolute Truth being God. Absolute Truth is only attained upon salvation. Prior to that stage we must attach ourselves to the truth as we see it, that is our own relative truths or beliefs about human need in society. At the same time, we ought to pursue these beliefs in a way which cares for the divine unity of all beings and should therefore be non-violent.

It was during his stay in South Africa that Gandhi went through the crucial stage of his spiritual development. He entered South Africa in 1893 as a shy, conventional lawyer; he left in 1914 as the architect of a new philosophy of non-violent resistance to oppression, which he called satyägraha, meaning "holding firmly to the truth". In South Africa, where oppression is still rife, Gandhi's philosophy of satyāgraha remains of vital importance.

Satyāgraha forms the ground plan of a distinctive way of life, both for the individual and for society at large. At the communal level, it is a systematic attempt to make creative use of social conflict. Satyägraha avoids the destructiveness of social conflict, and seeks to turn social conflict into a beneficient force towards the realization of truth, or the fulfilment of human need in society. In furtherance of its goal, satyägraha (1) issues a moral appeal; (2) when forced, employs techniques of non-cooperation and civil disobedience; and (3) engages in constructive work.

Central to satyāgraha is the moral challenge directed at one's opponent. Whereas in warfare, people set their faces against fraternization, or even cooperation, in saty $\bar{a}$ graha, contact with one's opponent is actively sought and any form of cooperation which is not at odds with the objectives of the campaign is positively encouraged. Satyagraha is a dialectical quest for truth. It aims at winning over one's opponent by the power of love and persuasion and by arousing in him a sense of justice rather than forcing him to submit out of fear or embarrassment.

12 MK Gandhi An Autobiography: the Story of my Experiments with Truth Navajivan Publishers, Ahmedabad, 1958, Non-violence in Peace and War (2 vols) Navajivan Publishers, Ahmedabad, 1948-1949, Sat yágraha in South Africa Navajivan Publishers, Ahmedabad, 1950; HJN Horsburgh Non-violence and Aggression Oxford University Press, 1968, Mahatma Gandhi Lutterworth, Woking, Surrey, 1972; Glyn Richards The Philosophy of Gandhi Curzon Press, 1982. 
If our search is for truth rather than victory, and our aim is to establish a society which actively seeks the fulfilment of all its members, we must restrict ourselves to the kind of means which produce such a society. To catch the nearest way and throw scruples to the winds, is to ensure that one will be directed further and further from the ultimate goal. To rush to the barricades in an effort to achieve an instant transformation of society is either to worsen oppression or to replace one form of oppression with another. Our methods should rather be directed at effecting a cooperative pursuit of the truth, and every effort should be made to set up a dialogue and to wring the last drain of human advantage out of situations of social conflict.

It may seem contradictory that satyägraha makes provision for techniques of noncooperation and civil disobedience. The answer is that cooperation must be consistent with the objectives of satyägraha, which cannot be amended until good reasons have been provided for altering them. When, despite repeated moral appeals, social conflict remains to be ignored or suppressed by terror, active resistance will commence, and techniques of non-cooperation and civil disobedience, though never of a violent nature, will be set in motion unless acceptable proposals are received before the stipulated time. Resistance, however, does not exhaust the moral requirements of the situation. In fact, resistance would be morally unjustifiable unless it is combined with "constructive work" or self-reliant schemes of reform, indicative of the positive thrust of satyāgraha towards the fulfilment of human need in society. From his earliest campaigns in South Africa onwards Gandhi has always emphasized the need for constructive work, for it not only promotes discipline, but confirms one's ends. Constructive work is essential to saty $\bar{a}$ graha. It is not just tacked on to resistance. On the contrary, it would be truer to say that resistance is tacked on to constructive work.

Finally, the effectiveness of satyāgraha depends on careful planning, moral qualities, and faith in the divine unity of all being. In order to succeed, its use must spring from conviction, not expediency.

In South Africa, satyāgraha was introduced by Gandhi himself, and during the 1950's found expression in the well-known Defiance Campaign. The campaigns led by Gandhi had a limited impact. ${ }^{13}$ The Defiance Campaign, on the other hand, met with apparent lack of success. Disillusionment set in, and in June 1961, the African National Congress announced that it was prepared to depart from its fifty-year old policy of non-violence to the extent that it would allow properly controlled violence, the government giving it no choice. ${ }^{14}$ Despite this, the idea of satyāgraha has remained alive within the ANC cadre and a host of other social organizations opposing the Apartheid system.

13 Cf Gandhi Satyágraha in South Africa; Fatima Meer Portrait of Indian South Africans Avon House, Durban, 1969, 23-32.

14 cf Mandela op cit; Tom Lodge Black Politics in South Africa since 1945 Raven Press, Johannesburg, 1983; Mokgethi Motlhabi The Theory and Practice of Black Resistance to Apartheid - A Social-ethical Analysis Skotaville Publishers, Johannesburg, 1984. Contrast the statement by Mandela to the effect that the Defiance Campaign had some definite results both nationally and internationally, though not in government circles. $N o$ Easy Walk to Freedom at 83; The Struggle is My Life at 92. 


\section{One South Africa, One Natural Law?}

Remains the question whether European, African, Islamic and Hindu forms of natural law thinking in South Africa could be turned into tributaries of one common stream which would lead to mutual understanding and, from there, to peaceful social reform. Of the utmost significance here is that the dignity of man is generally accepted as a universal principle of central importance. In this respect there exists consensus. However, conflict sets in when it comes to defining the meaning and conditions of the concept of human dignity.

In its barest form, the conflict is one of "right-consciousness" versus "duty-consciousness": whereas in the European mind the dignity of man is determined by his rights, according to traditional African, Islamic and Hindu thinking, man's dignity is related to his duties. This ideological conflict is not without practical consequences, as the following chart indicates: ${ }^{15}$

\begin{tabular}{|c|c|c|c|}
\hline & & Conflict model & Consensus model \\
\hline & Basic elements & rights & duties \\
\hline 2 & $\begin{array}{l}\text { Social life involves } \\
\text { is necessarily } \\
\text { and depends on or } \\
\text { generates }\end{array}$ & $\begin{array}{l}\text { inducement and coercion } \\
\text { divisive } \\
\text { structured conflict, } \\
\text { opposition, exclusion } \\
\text { and hostility }\end{array}$ & $\begin{array}{l}\text { commitments } \\
\text { cohesive } \\
\text { consensus, solidarity, } \\
\text { reciprocity, cooperation }\end{array}$ \\
\hline 3 & Leadership through & power & legitimate authority \\
\hline 4 & $\begin{array}{l}\text { Social systems are } \\
\text { and tend to }\end{array}$ & $\begin{array}{l}\text { ma lintegrated } \\
\text { and beset by contri- } \\
\text { dictions } \\
\text { change }\end{array}$ & $\begin{array}{l}\text { integrated } \\
\text { persist }\end{array}$ \\
\hline
\end{tabular}

In South Africa, today, social organization, in all spheres and at all levels, would seem to operate somewhere in between these two prototypes of social order. In fact, there might be more common ground in people's thinking than they realize or care to admit. At the level of governmental organization, the following two factors, in particular, deserve attention:

Of the utmost significance here is that the dignity of man is generally accepted as a universal principle of central importance. In this respect there exists consensus. How-

15 Adapted from PS Cohen Modern Social Theory Heinemann, London, 1968, 167. 
ever, conflict sets in when it comes to defining the meaning and conditions of the concept of human dignity.

In its barest form, the conflict is one of "right-consciousness" versus "duty-consciousness": whereas in the European mind the dignity of man is determined by his rights, according to traditional African, Islamic and Hindu thinking, man's dignity is related to his duties. This ideological conflict is not without practical consequences, as the following chart indicates: ${ }^{15}$

In South Africa today, social organization, in all spheres and at all levels, would seem to operate somewhere in between these two prototypes of social order. In fact, there might be more common ground in people's thinking than they realize or care to admit.

At the level of governmental organization, the following two factors, in particular, deserve attention:

(1) The Freedom Charter which was adopted by the Congress of the People on 26 June 1955, and to which the ANC adheres, firmly supports the idea of the protection of human rights, albeit within the confines of a unitary, social-welfare State. There is no clear indication that the ANC is committed to the modern African concept of the one-party-State. ${ }^{16}$ But even if it were or would become so committed, this would not necessarily affect its commitment to the Rule of Law. Prominent African socialist leaders, such as Julius Nyerere and Kenneth Kaunda, have repeatedly stated that the Rule of Law forms part of African Socialism. In April 1977, no less an authoritative body than the International Commission of Jurists ruled that the concept of the oneparty-State would not be inconsistent with the Rule of Law provided certain conditions were met. ${ }^{17}$

(2) In white political circles, the idea of consociationalism becomes ever more popular. Borrowed from overseas sources, ${ }^{18}$ and concerned with group rather than popular consensus, and with a confederal or federal structure rather than a unitary State, it does, however, acknowledge the notion of government by discussion and consensus.

What the policies just referred to have in common, is that they all reject a situation of "winner-takes-all". This is an important step in the direction of common legal standards.

It would, however, be naïve to believe that common legal standards will be arrived at easily. Before the stage of national reconciliation will be reached, a great deal more of social strife would seem to be inevitable. During that transitional stage, satyāgraha will hopefully have the upper-hand.

16 It is of interest to note here that Mandela when questioned by the court, during the 1956-1960 Treason Trial, about the concept of the one-party-State, replied that if democracy would be best expressed by a one-party system, he would examine the proposition very carefully. Cf No Easy Walk to Freedom at 84; The Struggle is my Life at 93.

17 Human Rights in a One-Party-State ICJ, Geneva, 1978.

18 Cf Arend Lÿphart Democracy in Plural Societies - a Comparative Exploration Yale University Press, 1977. 


\section{Conclusion}

Natural law thinking has a crucial role to play in shaping a new social order for South Africa. To be effective, however, it will have to take full account of the aspirations and realities of South African society. This implies a comparative natural law approach, supported by sociological studies. South Africa stands only at the beginning of this important task. 
problems arising from the 1973 law. But then a 1977 act facilitated the comeback of many traditional leaders to the newly reformed people's local courts. Again, this concided with the changing political color of the regime. Therefore, their pattern of development has become circular in nature.

The writer argues that there is a correlation between the various attempts for reforming customary law courts (or courts in general for that matter) and the political interests of those in power. He concludes that the examination of the history of local courts in Sudan not only reveals the nature of political relations between the center and the periphery but also tells us why each political regime wants to structure these relations differently.

Finally the writer suggests that the call for a unitary system is premature under conditions of cultural diversity that prevail in the country. If the legal system is to be efficient it must be grounded in the social system.

\section{Cultural and Social Identities in Africa: Chieftaincy and Political Change in Ghana}

\section{By Kwame Poku Annor}

The position of traditional chiefs in colonial and post-independence Ghana has been the subject of various enactments designed to regulate the functions of this office in the context of overall state administration.

Contrary to widely held expectations chieftaincy did not wither away in the process of independence and modernisation. The present factual situation of chiefs and their work is, however, not well explored. This article identifies some of the areas requiring detailed, systematic study and reports on research initiated in Ghana in this field.

\section{Conflict and Consensus in South African Natural Law Thinking}

By $A J G M$ Sanders

In South African society various currents of natural law thinking are discernible. Whereas to the European mind the dignity of man is determined traditionally by his rights, and society being rights-conscious is one of conflict, according to traditional African, Islamic, and Hindu thinking, man's dignity is related to his duties, and society is a consensus society. Practice, however, points towards a middle course, witness the 1955 Freedom Charter and the policy of consociationalism. It would, however be naive to believe that common standards will be arrived at easily. More social strife seems inevitable. In the long-term process of shaping a new order for South Africa comparative natural law studies, adequately backed by sociological research, could play a vital role. 